\title{
Resistance to stem canker (Leptosphaeria spp.) in interspecific Brassica hybrids
}

\section{Odporność mieszańców międzygatunkowych rodzaju Brassica na suchą zgniliznę kapustnych (Leptosphaeria spp.)}

\author{
Janetta Niemann ${ }^{1}$, Joanna Kaczmarek ${ }^{2 *}$, Andrzej Wojciechowski ${ }^{1}$, Małgorzata Jędryczka ${ }^{2}$
}

\begin{abstract}
Summary
Stem canker of brassicas (blackleg), caused by the fungi Leptosphaeria maculans and Leptosphaeria biglobosa, is one of the most destructive diseases of oilseed rape (Brassica napus) worldwide. Nowadays, the incorporation of Leptosphaeria resistance into Brassica lines with desirable agronomic and quality traits is a major concern in breeding programs. The aim of this study was to identify the sources of genetic resistance to stem canker in Brassica hybrids obtained from the crossings between two high yielding cultivars (Jet Neuf and Californium) of B. napus and B. carinata, B. fruticulosa, B. rapa ssp. chinensis and B. rapa ssp. pekinensis. The experiment was done in field conditions using $F_{1}$ and $F_{2}$ generations of these interspecific hybrids. Moreover, the determination of Leptosphaeria species was studied using Loop-mediated DNA Amplification (LAMP) method. The genotypes differed with their reaction to the pathogen. Between parental species the lowest percentage of infected plants were observed on the $B$. napus variety Jet Neuf and on $B$. carinata. Forms with increased resistance to blackleg especially among $B$. napus $\times$ B. carinata and $B$. napus $\times B$. fruticulosa hybrids have been found.
\end{abstract}

Key words: Brassica hybrids; blackleg; Leptosphaeria spp.; breeding for resistance

\section{Streszczenie}

Sucha zgnilizna kapustnych, powodowana przez grzyby workowe Leptosphaeria maculans i Leptosphaeria biglobosa jest jedną z najgroźniejszych chorób rzepaku w Polsce i na świecie. Obecnie, wprowadzanie odporności na grzyby rodzaju Leptosphaeria do genotypów Brassica o pożądanych cechach agronomicznych i jakościowych jest głównym celem wielu programów badawczych. Celem prezentowanych badań była identyfikacja źródeł odporności genetycznej na suchą zgniliznę kapustnych u mieszańców rodzaju Brassica, otrzymanych z krzyżowania między dwoma odmianami (Jet Neuf i Californium) B. napus i B. carinata, B. fruticulosa, B. rapa ssp. chinensis oraz $B$. rapa ssp. pekinensis. Doświadczenia przeprowadzone zostały na mieszańcach pokolenia $F_{1}$ i $F_{2} w$ warunkach polowych. Dodatkowo przy użyciu techniki LAMP (Loop-mediated DNA Amplification) określono przynależność gatunkową grzybów powodujących suchą zgniliznę kapustnych. Analizowane genotypy wykazały zróżnicowaną odporność na suchą zgniliznę kapustnych. Wśród gatunków rodzicielskich najmniejszy odsetek roślin porażonych stwierdzono na odmianie Jet Neuf B. napus oraz na B. carinata. Formy z podwyższoną odpornością na suchą zgniliznę kapustnych zaobserwowano głównie u mieszańców otrzymanych z krzyżowania między B. napus $\times$ B. carinata i B. napus $\times$ B. fruticulosa.

Słowa kluczowe: formy mieszańcowe Brassica; sucha zgnilizna kapustnych; Leptosphaeria spp.; hodowla odpornościowa

\footnotetext{
Uniwersytet Przyrodniczy w Poznaniu Katedra Genetyki i Hodowli Roślin

Dojazd 11, 60-632 Poznań

${ }^{2}$ Instytut Genetyki Roślin Polskiej Akademii Nauk

Strzeszyńska 34, 60-479 Poznań

*corresponding author: jkac@igr.poznan.pl
} 


\section{Wstęp / Introduction}

Sucha zgnilizna kapustnych jest jedną z najgroźniejszych chorób w Polsce i na świecie. W Polsce straty plonu powodowane przez suchą zgniliznę kapustnych mogą wynosić nawet 60\% (Gwiazdowski i wsp. 2008). Porażenie roślin powodowane jest przez grzyby workowe Leptosphaeria maculans (Desm.) Ces et de Not. oraz Leptosphaeria biglobosa (Shoemaker i Brun 2001) należące do podtypu Ascomycotina, klasy Dothideomycetes, rzędu Pleosporales. W wielu krajach, włączając Polskę oba gatunki patogena prowadzą do poważnych uszkodzeń roślin rzepaku ozimego oraz znacznych strat plonu nasion (Jędryczka 2006; Korbas i wsp. 2008). Gatunki te różnią się pod względem chorobotwórczości wobec rzepaku, przy czym L. maculans jest gatunkiem bardziej agresywnym, odpowiedzialnym za większe straty plonu niż L. biglobosa (Fitt i wsp. 2006). Na różnych kontynentach sucha zgnilizna kapustnych występuje $\mathrm{z}$ różnym nasileniem, spowodowanym odmiennym klimatem, doborem odmian, a także technologią uprawy rzepaku (Kauzik i wsp. 2009). Stopień porażenia zależy między innymi od wielu czynników, takich jak: miejsce uprawy, stadium rozwoju rośliny oraz od warunków pogodowych, które w różnym stopniu mogą wpływać na rozwój choroby.

Znane są dwa typy odporności na $L$. maculans (Delourme i wsp. 2004). Na poziomie siewki i młodych roślin działa odporność pionowa - rasowo-specyficzna, kontrolowana przez pojedyncze geny główne, np. gen $\operatorname{Rlm} 7$ (Ferreira i wsp. 1995; Mayerhofer i wsp. 1997). Natomiast pozioma odporność poligeniczna, częściowa, występuje u dojrzałych roślin zwykle po wernalizacji i kontrolowana jest przez wiele czynników genetycznych; jest ona kodowana przez loci cech ilościowych (QTL Quantitative Trait Loci) (Gout i wsp. 2006). Niewiele jednak wiadomo na temat mechanizmów odporności rzepaku na L. biglobosa (Fitt i wsp. 2006).

W celu ochrony rzepaku przed suchą zgnilizną kapustnych hodowcy korzystają zarówno z odporności poziomej, która uchodzi za trwałą - trudną do pokonania przez nowe rasy patogena, jak i pionowej, która uchodzi za wyjątkowo silną, ale możliwą do przełamania. Odporność pionowa wymaga ciągłego odnawiania poprzez wprowadzanie nowych genów do rzepaku (krzyżowanie $\mathrm{z}$ roślinami posiadającymi nowe geny odporności). Jest to niezbędne ze względu na periodyczne zmiany populacji patogena oraz z uwagi na fakt, że ochrona roślin rzepaku związana $\mathrm{z}$ tą odpornością jest skuteczna jedynie przez okres kilku lat. Ma na to wpływ sposób rozmnażania patogena (w przypadku grzybów rodzaju Leptosphaeria może to być zarówno cykl płciowy, jak i bezpłciowy) oraz skłonność określonych fragmentów genomu do mutacji i obecność czynników mutagennych w środowisku.

Dzięki prowadzonym pracom hodowlanym możliwe staje się łączenie tych dwóch źródeł odporności i uzyskiwanie tzw. podwójnej odporności na suchą zgniliznę kapustnych. Dotychczas taką cechą wyróżniają się między innymi nowe odmiany rzepaku, tj. Arsenal, Anderson i Atenzo, DK Exstorm, PT 234.

Dotychczas opisano 14 genów odporności na $L$. maculans (Rlm1-Rlm10 oraz LepR1-LepR4) pochodzących
Z różnych gatunków Brassica. Z B. rapa przeniesiono gen $R \operatorname{lm} 8$ (Balesdent i wsp. 2002), natomiast $\mathrm{z}$ B. napus pochodzą geny $R \operatorname{lm} 1-R \operatorname{lm} 4, R \operatorname{lm} 7$ i $R \operatorname{lm} 9$ (Delourme i wsp. 2004). Ponadto, Siemens (2002) wykazał, że B. fruticulosa również może stanowić cenne źródło odporności na suchą zgniliznę kapustnych. Rahman i wsp. (2007) stwierdzili, że $B$. carinata posiada unikalny zestaw genów odporności na suchą zgniliznę kapustnych, który jest znacznie skuteczniejszy od źródeł odporności uzyskiwanych z B. napus. Wprowadzenie w 1977 roku na rynek odmiany Jet Neuf posiadającej zarówno główny gen odporności $R \operatorname{lm} 4$, jak również odporność poligeniczną, pozwoliło na skuteczne ograniczenie występowania suchej zgnilizny kapustnych w Europie (Balesdent i wsp. 2001).

Według Starzyckiej i wsp. (2009) obecnie podstawowym celem hodowli odpornościowej rzepaku ozimego jest otrzymanie nowych odmian, które w warunkach naturalnych nie ulegają porażeniu przez patogeny. Prowadząc prace mające na celu introdukcję genów odporności z dzikich gatunków rodzaju Brassica do rzepaku, niezmiernie istotne jest określenie podatności nowo wyprowadzanych mieszańców rzepaku na grzyby L. maculans i L. biglobosa.

Celem pracy była ocena odporności mieszańców Brassica otrzymanych na drodze krzyżowania oddalonego między wybranymi odmianami rzepaku ozimego i gatunkami będącymi potencjalnymi nosicielami genów odporności na grzyby powodujące suchą zgniliznę kapustnych.

\section{Materiały i metody / Materials and methods}

Materiał badawczy stanowiły rośliny pokolenia $\mathrm{F}_{1} \mathrm{i}_{2}$ mieszańców międzygatunkowych $B$. napus $\times B$. fruticulosa (10 potomstw), B. napus $\times B$. carinata $(10$ potomstw $)$, $B$. napus $\times$ B. rapa ssp. pekinensis $(10$ potomstw $)$ oraz B. napus $\times$ B. rapa ssp. chinensis $(10$ potomstw), a także formy wyjściowe użyte do krzyżowań (6 genotypów). Rośliny mieszańcowe otrzymano na drodze kultur in vitro izolowanych zarodków (Wojciechowski 1993), przy czym jako formy mateczne wykorzystano dwie odmiany rzepaku ozimego, tj. Californium (Monsanto Polska Sp. z o.o.) i Jet Neuf (Francja). Obserwacje zdrowotności roślin rzepaku przeprowadzono jesienią 2014 roku (pokolenie $F_{1}$ ) i jesienią 2015 roku (pokolenie $F_{2}$ ) w fazie rozwojowej BBCH 19 w Rolniczym Gospodarstwie Doświadczalnym w Dłoni koło Rawicza. Doświadczenie założono w układzie bloków kompletnie zrandomizowanych na poletkach o powierzchni $10 \mathrm{~m}^{2} \mathrm{w}$ trzech powtórzeniach. Siew wykonano 22 sierpnia 2014 roku i 24 sierpnia 2015 roku. Źródłem porażenia roślin było naturalnie występujące inokulum patogenów powodujących suchą zgniliznę kapustnych. Na każdym poletku oceniano po 50 roślin. Wyniki przedstawiono jako średni odsetek roślin porażonych. Z każdej rośliny $\mathrm{z}$ objawami suchej zgnilizny kapustnych pobierano fragmenty tkanek, które dezynfekowano, a następnie w warunkach sterylnych wykładano na pożywkę agarową PDA (Potato Dextrose Agar) $\mathrm{z}$ dodatkiem $0,02 \%$ siarczanu streptomycyny. Po 2 dniach z wyrastającej kolonii grzyba pobierano pod binokularem (Stemi DR 1040, Zeiss, Niemcy) końcowy fragment poje- 
dynczej strzępki w celu uzyskania izolatów jednolitych genetycznie. Fragment ten przenoszono na szalki ze świeżą pożywką PDA z dodatkiem 0,02\% siarczanu streptomycyny, aż do uzyskania kultur wolnych od bakterii i innych patogenów. Czystość izolatów sprawdzano poprzez ich hodowlę na płynnej pożywce Czapka-Doxa $\mathrm{Z}$ dodatkiem ekstraktu drożdżowego (2 g/l). Po kilku dniach hodowli klarowna pożywka świadczyła o braku zanieczyszczeń bakteryjnych. Dla każdego genotypu otrzymano po 45 izolatów. DNA (deoxyribonucleic acid kwas deoksyrybonukleinowy) izolatów ekstrahowano z wykorzystaniem CTAB (cetyltrimethyl ammonium bromide - bromek heksadecylotrimetylo-amoniowy) i mieszaniny chloroformu oraz alkoholu izoamylowego w proporcji 24:1, według Grahama i wsp. (1994) z modyfikacjami własnymi. Do oceny przynależności gatunkowej sprawców suchej zgnilizny kapustnych zastosowano technikę izotermicznej amplifikacji DNA z zastosowaniem starterów zapętlających (LAMP - Loop-mediated Isothermal Amplification). Reakcję prowadzono w $10 \mu \mathrm{l}$, a mieszanina zawierała: 1,6 $\mu \mathrm{M}$ FIP i 1,6 $\mu \mathrm{M}$ BIP, 0,2 $\mu \mathrm{M}$ F3 i $0,2 \mu \mathrm{M}$ B3, 0,8 $\mu \mathrm{M}$ LoopF i 0,8 $\mu \mathrm{M}$ LoopB (Jędryczka i wsp. 2013), $1 \mu$ l Isothermal Mastermix - fluorescent Dye 1x (Optigene, Wielka Brytania), $1 \mu$ l DNA oraz $1 \mu \mathrm{l}$ wody. Reakcję prowadzono w temperaturze $64^{\circ} \mathrm{C}$ przez 60 minut w aparacie do Real-Time PCR (CFX96, BioRad). Wnioskowanie dotyczące istotności różnic między obiektami badawczymi prowadzono na podstawie jednoczynnikowej analizy wariancji, a istotność różnic określono testem Tukeya, przyjmując poziom istotności $\alpha=0,05$. Obliczenia wykonano stosując pakiet statystyczny STATISTICA v. 6.0 (Stat Soft).

\section{Wyniki i dyskusja / Results and discussion}

Ze względu na duże straty plonu, a co się z tym wiąże zysków z uprawy rzepaku, z powodu grzybów L. maculans i L. biglobosa w wielu krajach od lat prowadzi się programy badawcze, których celem jest otrzymanie odmian odpornych na suchą zgniliznę kapustnych. Tego typu prace hodowlane opierają się na krzyżowaniu wewnątrzgatunkowym, międzygatunkowym i międzyrodzajowym, mutagenezie, transformacji genetycznej i klonowaniu odpornych osobników (Siemens 2002; Delourme i wsp. 2004; Rahman i wsp. 2007).

$\mathrm{W}$ niniejszych badaniach testowano podatność mieszańców $\mathrm{F}_{1}$ i $\mathrm{F}_{2}$ otrzymanych $\mathrm{w}$ wyniku krzyżowania międzygatunkowego dwóch odmian rzepaku z wybranymi gatunkami rodzaju Brassica, mogącymi być potencjalnymi donorami genów odporności na Leptosphaeria spp.

Wśród komponentów rodzicielskich w obu sezonach badawczych największy odsetek nieporażonych roślin stwierdzono u odmiany Jet Neuf oraz u formy $B$. carinata (tab. 1, 2). Z kolei na B. rapa ssp. pekinensis i B. rapa ssp. chinensis procent porażenia roślin był istotnie statystycznie wyższy. Grupy roślin potomnych pochodzących z krzyżowania między formami rodzicielskimi wykazywały odmienny zakres zmienności cechy odporności na porażenie przez grzyby Leptosphaeria spp. Generalnie, u mieszańców otrzymanych z krzyżowań między $B$. napus a $B$. carinata i B. fruticulosa, w każdym roku badań obserwowano mniejszy zakres zmienności niż w przypadku mieszańców $B$. napus $\times B$. rapa. Ponadto, wśród mieszańców $B$. napus $\times B$. carinata pojawiły się genotypy o wyższej odporności na suchą zgniliznę kapustnych w porównaniu do mniej wrażliwego rodzica dla mieszańców $\mathrm{F}_{1} B$. napus $\times B$. carinata i gatunku $B$. carinata, odpowiednio. Także wśród mieszańców $B$. napus $\times B$. fruticulosa można było wyselekcjonować rośliny o podwyższonej odporności w stosunku do gatunków rodzicielskich. Podobną prawidłowość zaobserwowano również oceniając odporność na roślinach drugiego pokolenia mieszańców (tab. 2). Szczególnie w kombinacjach krzyżowania z $B$. carinata, w których roślinę mateczną stanowiła odmiana rzepaku Jet Neuf, w obu sezonach badawczych pojawiły się rośliny odporne na porażenie przez Leptosphaeria spp. Średnie porażenie roślin mieszańcowych przez oba patogeny powodujące suchą zgniliznę kapustnych wynosiło $10,5 \%$ w pokoleniu $F_{1}$, a form rodzicielskich niewiele więcej bo $12,1 \%$, niemniej była to różnica na korzyść populacji roślin potomnych. Jesienią 2015 roku porażenie roślin było mniejsze niż w sezonie poprzednim $\mathrm{i}$ wahało się $\mathrm{u}$ form rodzicielskich od 3 do $5,7 \%$, a u mieszańców pokolenia $F_{2}$ od 1,7 do $8,3 \%$. Najmniejsze porażenie, podobnie jak $\mathrm{w}$ pokoleniu $\mathrm{F}_{1}$, obserwowano na mieszańcach otrzymanych w wyniku krzyżowania rzepaku z B. carinata i $B$. fruticulosa, co mogło być efektem przeniesienia genów odporności na suchą zgniliznę kapustnych $\mathrm{z}$ tych dwóch gatunków dzikich i otrzymania mieszańcowego potomstwa $\mathrm{z}$ podwyższoną odpornością.

Podczas wykonywania obserwacji roślin losowo pobierano liście $\mathrm{z}$ objawami suchej zgnilizny kapustnych i izolowano oraz identyfikowano patogeny wywołujące objawy chorobowe. Analizę ich przynależności gatunkowej przeprowadzono za pomocą techniki LAMP, która jest metodą amplifikacji kwasów nukleinowych pozwalającą na szybką i specyficzną identyfikację patogenów w warunkach izotermicznych - stałotemperaturowych (Jędryczka i wsp. 2013). W Polsce zakres i nasilenie występowania obu patogenów jest zróżnicowany i podlega ciągłym zmianom. Dwadzieścia lat temu obserwowano niemal wyłącznie gatunek L. biglobosa, jednak od tamtego czasu obserwuje się wzrost udziału gatunku L. maculans i jego ekspansję z zachodu na wschód, przy czym nadal stwierdza się zmiany składu populacji patogenów w czasie i przestrzeni (Karolewski 1998; Jędryczka 2006). Przeprowadzone analizy pokazały jednoznacznie, że w okresie jesiennym objawy chorobowe wywoływane były głównie przez gatunek L. maculans (62,3 do 84\% badanej puli). Dominację grzyba $L$. maculans na liściach rzepaku wykazała Jędryczka (2006) w badaniach prowadzonych w latach 2000-2004, a następnie w latach 2009-2010 także Kaczmarek (2010). Badania Kaczmarek i wsp. (2011) wykazały także, że proporcje między gatunkami L. maculans i L. biglobosa w znacznym stopniu zależały od okresu, w którym wykonywano obserwacje, a co się z tym wiąże są różne, na poszczególnych organach roślinnych. W okresie jesiennym na liściach zwykle przeważał gatunek L. maculans, natomiast na łodygach dominował gatunek L. biglobosa. 
W niniejszych badaniach w pierwszym roku obserwacji nie stwierdzono statystycznie istotnych różnic między formami rodzicielskimi i ich mieszańcami a udziałem grzybów L. maculans lub L. biglobosa w powodowaniu objawów. W drugim sezonie można było takie różnice zauważyć. Najwyższy odsetek objawów chorobowych powodowanych przez L. maculans stwierdzono na mieszańcach z B. rapa ssp. pekinensis i był on istotnie większy niż u mieszańców $\mathrm{z} B$. carinata. Najmniej izolatów L. biglobosa uzyskano z liści mieszańca B. napus odmiany Californium $\times$ B. rapa ssp. pekinensis.

Tabela 1. Procent mieszańców $F_{1}$ i form rodzicielskich z objawami suchej zgnilizny kapustnych jesienią 2014 roku oraz procentowy udział gatunków Leptosphaeria maculans i Leptosphaeria biglobosa na testowanych roślinach (BBCH 19)

Table 1. The percentage of $F_{1}$ hybrid plants and parental genotypes with phoma leaf spot symptoms in autumn 2014 and the percentage of Leptosphaeria maculans and Leptosphaeria biglobosa in tested plants (BBCH 19)

\begin{tabular}{|c|c|c|c|c|}
\hline \multirow{2}{*}{$\begin{array}{l}\text { Forma rodzicielska/mieszaniec } \\
\text { Parental forms/hybrids }\end{array}$} & \multirow{2}{*}{$\begin{array}{l}\% \text { porażonych roślin } \\
\% \text { of infected plants }\end{array}$} & \multirow{2}{*}{$\begin{array}{l}\text { Zakres zmienności } \\
\text { Range of variability }\end{array}$} & \multicolumn{2}{|c|}{$\%$ izolatów $-\%$ of isolates } \\
\hline & & & $\begin{array}{l}\text { Leptosphaeria } \\
\text { maculans }\end{array}$ & $\begin{array}{l}\text { Leptosphaeria } \\
\text { biglobosa }\end{array}$ \\
\hline Brassica napus odm. - cv. Californium & $13,0 \mathrm{bc}$ & $8,0-17,3$ & $81,3 \mathrm{a}$ & $18,7 \mathrm{a}$ \\
\hline Brassica napus odm. - cv. Jet Neuf & $5,3 \mathrm{a}$ & $3,0-9,3$ & $73,0 \mathrm{a}$ & $27,0 \mathrm{a}$ \\
\hline Brassica rapa ssp. pekinensis & $28,7 \mathrm{~d}$ & $25,0-34,7$ & $78,7 \mathrm{a}$ & $21,3 \mathrm{a}$ \\
\hline Brassica rapa ssp. chinensis & $16,3 \mathrm{~cd}$ & $12,0-20,3$ & $70,0 \mathrm{a}$ & $30,0 \mathrm{a}$ \\
\hline Brassica carinata & $3,0 \mathrm{a}$ & $1,3-5,0$ & $71,3 \mathrm{a}$ & $28,7 \mathrm{a}$ \\
\hline Brassica fruticulosa & $6,3 \mathrm{a}$ & $3,3-9,0$ & $71,3 \mathrm{a}$ & $28,6 \mathrm{a}$ \\
\hline $\begin{array}{l}\text { Brassica napus odm. }-\mathrm{cv} \text {. Californium } \times \\
\text { Brassica rapa } \text { ssp. chinensis }\end{array}$ & $14,7 \mathrm{c}$ & $9,0-19,3$ & 83,7 a & $16,3 \mathrm{a}$ \\
\hline $\begin{array}{l}\text { Brassica napus odm. }-\mathrm{cv} \text {. Californium } \times \\
\text { Brassica rapa } \mathrm{ssp} \text {. pekinensis }\end{array}$ & $21,7 \mathrm{~d}$ & $18,3-26,3$ & $84,0 \mathrm{a}$ & $16,0 \mathrm{a}$ \\
\hline $\begin{array}{l}\text { Brassica napus odm. }-\mathrm{cv} \text {. Californium } \times \\
\text { Brassica carinata }\end{array}$ & $2,7 \mathrm{a}$ & $1,3-3,7$ & 69,3 a & $30,7 \mathrm{a}$ \\
\hline $\begin{array}{l}\text { Brassica napus odm. - cv. Californium } \times \\
\text { Brassica fruticulosa }\end{array}$ & $5,7 \mathrm{a}$ & $2,0-7,3$ & 70,3 a & $29,7 \mathrm{a}$ \\
\hline $\begin{array}{l}\text { Brassica napus odm. }- \text { cv. Jet Neuf } \times \\
\text { Brassica rapa } \mathrm{ssp} \text {. chinensis }\end{array}$ & $15,0 \mathrm{c}$ & $7,0-17,3$ & $75,3 \mathrm{a}$ & $24,7 \mathrm{a}$ \\
\hline $\begin{array}{l}\text { Brassica napus odm. }- \text { cv. Jet Neuf } \times \\
\text { Brassica rapa } \mathrm{ssp} \text {. pekinensis }\end{array}$ & $15,3 \mathrm{~cd}$ & $9,0-19,3$ & 82,3 a & $17,6 \mathrm{a}$ \\
\hline $\begin{array}{l}\text { Brassica napus odm. }- \text { cv. Jet Neuf } \times \\
\text { Brassica carinata }\end{array}$ & $2,7 \mathrm{a}$ & $0,0-4,3$ & $77,3 \mathrm{a}$ & $22,6 \mathrm{a}$ \\
\hline $\begin{array}{l}\text { Brassica napus odm. - cv. Jet Neuf } \times \\
\text { Brassica fruticulosa }\end{array}$ & $6,7 \mathrm{ab}$ & $2,3-9,7$ & $72,3 \mathrm{a}$ & $27,7 \mathrm{a}$ \\
\hline
\end{tabular}

odm. - cv. - odmiana - cultivar

Średnie w kolumnach oznaczone tą samą literą nie różnią się między sobą na poziomie istotności $\alpha=0,05$

Means in columns followed by shared letters denote no statistical differences at $\alpha=0.05$

Tabela 2. Procent mieszańców $F_{2}$ i form rodzicielskich $\mathrm{z}$ objawami suchej zgnilizny kapustnych jesienią 2015 roku oraz procentowy udział gatunków Leptosphaeria maculans i Leptosphaeria biglobosa na testowanych roślinach (BBCH 19)

Table 2. The percentage of $F_{2}$ hybrid plants and parental genotypes with phoma leaf spot symptoms in autumn 2015 and the percentage of Leptosphaeria maculans and Leptosphaeria biglobosa in tested plants (BBCH 19)

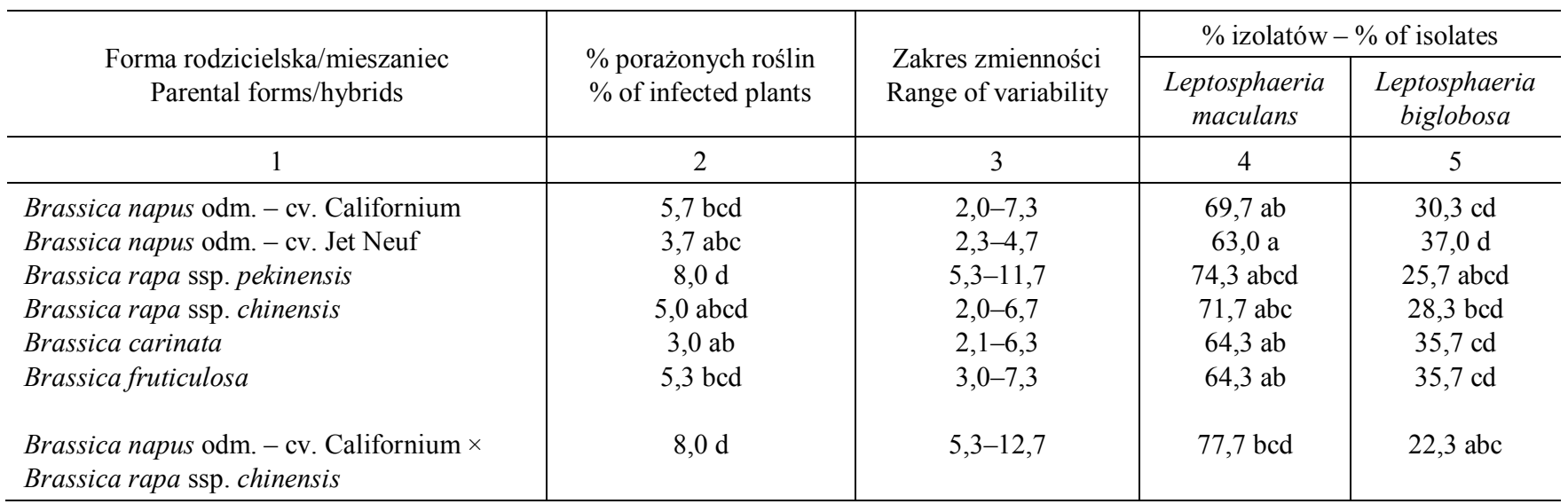




\begin{tabular}{|c|c|c|c|c|}
\hline 1 & 2 & 3 & 4 & 5 \\
\hline $\begin{array}{l}\text { Brassica napus odm. }-\mathrm{cv} . \text { Californium } \times \\
\text { Brassica rapa } \mathrm{ssp} \text {. pekinensis }\end{array}$ & $7,0 \mathrm{~cd}$ & $5,0-10,3$ & $86,3 \mathrm{~d}$ & $13,7 \mathrm{a}$ \\
\hline $\begin{array}{l}\text { Brassica napus odm. }-\mathrm{cv} . \text { Californium } \times \\
\text { Brassica carinata }\end{array}$ & $1,7 \mathrm{a}$ & $1,1-2,3$ & $62,3 \mathrm{a}$ & $37,7 \mathrm{~d}$ \\
\hline $\begin{array}{l}\text { Brassica napus odm. - cv. Californium } \times \\
\text { Brassica fruticulosa }\end{array}$ & $1,7 \mathrm{a}$ & $0,3-2,7$ & $63,3 \mathrm{a}$ & $36,7 \mathrm{~d}$ \\
\hline $\begin{array}{l}\text { Brassica napus odm. - cv. Jet Neuf } \times \\
\text { Brassica rapa } \mathrm{ssp} \text {. chinensis }\end{array}$ & $8,3 \mathrm{~d}$ & $6,1-10,7$ & $68,3 \mathrm{ab}$ & $31,7 \mathrm{~cd}$ \\
\hline $\begin{array}{l}\text { Brassica napus odm. }- \text { cv. Jet Neuf } \times \\
\text { Brassica rapa } \mathrm{ssp} \text {. pekinensis }\end{array}$ & $8,0 \mathrm{~d}$ & $5,7-9,7$ & $84,0 \mathrm{~cd}$ & $16,0 \mathrm{ab}$ \\
\hline $\begin{array}{l}\text { Brassica napus odm. - cv. Jet Neuf } \times \\
\text { Brassica carinata }\end{array}$ & $2,3 \mathrm{ab}$ & $0,3-3,3$ & $65,7 \mathrm{ab}$ & $34,3 \mathrm{~cd}$ \\
\hline $\begin{array}{l}\text { Brassica napus odm. - cv. Jet Neuf } \times \\
\text { Brassica fruticulosa }\end{array}$ & $3,7 \mathrm{abc}$ & $2,0-5$ & 75,3 abcd & 24,7 abcd \\
\hline
\end{tabular}

odm. - cv. - odmiana - cultivar

Średnie w kolumnach oznaczone tą samą literą nie różnią się między sobą na poziomie istotności $\alpha=0,05$

Means in columns followed by shared letters denote no statistical differences at $\alpha=0.05$

\section{Wnioski / Conclusions}

1. W obu sezonach badawczych, spośród komponentów rodzicielskich najmniejszy odsetek roślin porażonych przez Leptosphaeria spp. stwierdzono na odmianie rzepaku Jet Neuf oraz na gatunku $B$. carinata.

2. Wśród mieszańców $B$. napus $\times B$. carinata oraz B. napus $\times$ B. fruticulosa można wyselekcjonować formy o wyższej odporności na suchą zgniliznę kapustnych w porównaniu do mniej wrażliwego rodzica.
3. Objawy chorobowe występujące na badanych roślinach rzepaku w latach 2014-2015 wywoływane były głównie przez gatunek L. maculans.

\section{Podziękowanie / Acknowledgements}

Badania zrealizowano w ramach projektu Ministerstwa Rolnictwa i Rozwoju Wsi, zadanie 54: Introdukcja genów odporności na choroby i owady oraz męskiej sterylności z pokrewnych gatunków rodzaju Brassica do rzepaku (Brassica napus L.).

\section{Literatura / References}

Balesdent M.H., Attard A., Ansan-Melayah D., Delourme R., Renard M., Rouxel T. 2001. Genetic control and host range of avirulence towards Brassica napus cultivars Quinta and Jet Neuf in Leptosphaeria maculans. Phytopathology 91: 70-76.

Balesdent M.H., Attard A., Kuhn A.L., Rouxel T. 2002. New avirulence genes in the phytopathogenic fungus Leptosphaeria maculans. Phytopathology 92: 1122-1133.

Delourme R., Pilet-Nayel M.L., Archipiano M., Horvais R., Tanguy X., Rouxel T., Brun H., Renard M., Balesdent M.H. 2004. A cluster of major specific resistance genes to Leptosphaeria maculans in Brassica napus. Phytopathology 94: 578-583.

Ferreira M.E., Rimmer S.R., Williams P.H., Osborn T.C. 1995. Mapping loci controlling Brassica napus to Leptosphaeria maculans under different screening conditions. Phytopathology 85: 213-217.

Fitt B.D.L., Brun H., Barbetti M.J., Rimmer S.R. 2006. World-wide importance of phoma stem canker (Leptosphaeria maculans and L. biglobosa) on oilseed rape (Brassica napus). European Journal of Plant Pathology 114: 3-15.

Gout L., Fudal I., Kühn M.L., Blaise F., Eckert M., Cattolico L., Balesdent M.H., Rouxel T. 2006. Lost in the middle of nowhere: the AvrLm1 avirulence gene of the Dothideomycete Leptosphaeria maculans. Molecular Microbiology 60 (1): 67-80.

Graham G.C., Mayers P., Henry R.J. 1994. A simplified method for the preparation of fungal genomic DNA for PCR and RAPD analysis. Biotechniques 16 (1): 48-50.

Gwiazdowski R., Korbas M., Jajor E. 2008. Ochrona rzepaku przed chorobami. s. 42-55. W: „Integrowana produkcja rzepaku ozimego i jarego" (M. Mrówczyński, S. Pruszyński, red.). Instytut Ochrony Roślin, Poznań, 107 ss.

Jędryczka M. 2006. Epidemiologia i szkodliwość suchej zgnilizny kapustnych na rzepaku ozimym w Polsce. Rozprawy i Monografie Instytutu Genetyki Roślin Polskiej Akademii Nauk 17, 150 ss.

Jędryczka M., Burzyński A., Brachaczek A., Langwiński W., Song P., Kaczmarek J. 2013. Loop-mediated isothermal amplification as a good tool to study changing Leptosphaeria populations in oilseed rape plants and air samples. Acta Agrobotanica 67 (4): $93-100$.

Kaczmarek J. 2010. Rozwój stadium generatywnego grzybów Leptosphaeria maculans ([Desm.] Ces. et de Not.) i L. biglobosa (Shoemaker i Brun 2001) oraz ochrona rzepaku przed tymi patogenami. Praca doktorska. Instytut Genetyki Roślin Polskiej Akademii Nauk, Poznań, 238 ss.

Kaczmarek J., Brachaczek A., Jędryczka M. 2011. Wpływ terminu stosowania fungicydu zawierającego flusilazol na skuteczność ochrony rzepaku ozimego przed suchą zgnilizną kapustnych. Rośliny Oleiste - Oilseed Crops 32 (2): 153-166. 
Karolewski Z. 1998. The influence of fungicides on Phoma lingam (Tode ex. Fr.) Desm. mycelium growth. IOBC/WPRS Bulletin 21: 33-39.

Kauzik M., Starzycka E., Starzycki M. 2009. Postęp w badaniach nad suchą zgnilizną kapustnych (Leptosphaeria ssp.). Rośliny Oleiste - Oilseed Crops 30: 223-243.

Korbas M., Horoszkiewicz-Janka J., Jajor E. 2008. Uproszczone systemy uprawy a występowanie sprawców chorób. [Simplified systems of soil management in relation to the occurrence of disease casual agents]. Progress in Plant Protection/Postępy w Ochronie Roślin 48 (4): 1431-1438.

Mayerhofer R., Bansal V.K., Thiagarajah M.R., Stringam G.R., Good A.G. 1997. Molecular mapping of resistance to Leptosphaeria maculans in Australian cultivars of Brassica napus. Genome 40: 294-301.

Rahman M.H., Hawkins G., Avery M., Thiagarajah M.R., Sharpe A.G., Lange R.M., Bansal V., Stringam G.R. 2007. Introgression of blackleg (Leptosphaeria maculans) resistance into Brassica napus from B. carinata and identifications of microsatellite (SSR) markers. Proceedings of the 12th International Rapeseed Congress. China, Wuhan, 26-30.03.2007. 4: 47-50.

Shoemaker R.A., Brun H. 2001. The teleomorph of the weakly aggressive segregate of Leptosphaeria maculans. Canadian Journal of Botany 79: 412-419.

Siemens J. 2002. Interspecific hybridization between wild relatives and Brassica napus to introduce new resistance traits into the oilseed rape gene pool. Czech Journal of Genetics and Plant Breeding 38: 155-157.

Starzycka E., Starzycki M., Kauzik M., Woś H., Cichy H., Budzianowski G. 2009. Ocena odporności rzepaku ozimego na porażenie przez Leptosphaeria spp. i Sclerotinia sclerotiorum (Lib.) de Bary w doświadczeniach przeprowadzonych w Małyszynie i Borowie w latach 2007-2009. Rośliny Oleiste - Oilseed Crops 30: 207-222.

Wojciechowski A. 1993. Some morfological and phenological traits and fertility of lines of artificial winter oilseed rape originated from male-sterile plants (Brassica napus var. oleifera L.). Genetica Polonica 34 (4): 317-325. 